\title{
Ervaringen met een Basiskwalificatie Onderwijs voor studenten (BKO-S)
}

T. Verbeek, R.G. Pleijhuis, A.J.G. van Kleef, M.E. Stegmann, L. Schultinge, A.W. Sillius, F.M. Bos, W.M. Molenaar

\section{Samenvatting}

Inleiding: De Basiskwalificatie Onderwijs (BKO) is een bewijs van didactische bekwaamheid voor universitaire docenten. Binnen het Universitair Medisch Centrum Groningen (UMCG) rees de vraag naar een soortgelijke kwalificatie voor studenten. Er werden twee moeilijkheden voorzien: de (on)mogelijkheid voor studenten om didactische scholingsactiviteiten naast hun curriculum in te roosteren en het opdoen van onderwijservaring.

Opzet: Er werd een opleidingstraject (BKO-S) ontwikkeld voor studenten geneeskunde, tandheelkunde en bewegingswetenschappen met gelijke eindtermen als het BKO-traject voor docenten. Om aan het roosterprobleem tegemoet te komen werd het traject gespreid over vier jaar en werd een deel van de trainingen ondergebracht in Summer Schools. Door BKO-studenten reguliere onderwijsfuncties te laten verzorgen werd aan de tweede moeilijkheid tegemoet gekomen. Omdat de omvang van de praktijkervaring van de gemiddelde student achter zal blijven bij die van de gemiddelde docent in het BKO-traject wordt aan studenten een BKO-S certificaat gegeven met daarbij een portfolio beoordelingsverslag waarin de onderwijservaring wordt gespecificeerd.

Resultaten: In 2008 en 2009 begonnen respectievelijk twaalf en zestien studenten aan het BKO-S traject. De deelname aan de ingeroosterde trainingen en de Summer Schools was hoog. Naast het vervullen van reguliere onderwijstaken bleken studenten zeer creatief in het vinden van mogelijkheden om onderwijservaring op te doen. Op de peildatum van 1 augustus 2011 hebben de eerste twee studenten het traject afgerond en zijn hun portfolio's goedgekeurd. Studenten ontvangen het BKO-S certificaat met hun Masterdiploma.

Discussie/conclusie: Het is mogelijk gebleken studenten een extracurriculair didactisch scholingsprogramma te laten volgen dat vergelijkbaar is met het BKO-programma voor docenten. (Verbeek T, Pleijhuis RG, Kleef AJG van, Stegmann ME, Schultinge L, Sillius AW, Bos $F M$, Molenaar WM. Ervaringen met een Basiskwalificatie Onderwijs voor studenten (BKO-S). Tijdschrift voor Medisch Onderwijs 2011;30(6):272-282.)

\section{Inleiding}

Hoewel dit jaren het geval leek te zijn binnen de universiteit, is vakinhoudelijke kennis voor docenten niet het enige dat zij nodig hebben om goed onderwijs te kunnen geven. Voor alle docenten geldt immers dat zij daarnaast over didactische vaardigheden moeten beschikken. Binnen de Nederlandse universiteiten kreeg de professionalisering van docenten begin 2008 een impuls door de onderlinge erkenning van de Basiskwalificatie Onderwijs (BKO) als bewijs van didactische bekwaamheid voor docenten in het universitaire onderwijs. ${ }^{1}$ In een kaderregeling zijn de minimale eisen opgenomen waaraan een BKO moet voldoen met betrekking tot inhoud, toetsing en proces. ${ }^{2}$ In deze regeling zijn contouren geschetst om uniformiteit tussen universiteiten te bevorderen, terwijl tegelijkertijd 
ruimte wordt geboden om het professionaliseringstraject op eigen wijze in te vullen. Van startende docenten wordt verwacht dat zij al een BKO hebben, of deze in een vroegtijdig stadium halen. Voor zittende docenten worden docentkwalificaties nog nadrukkelijker onderdeel van hun functioneringsgesprekken. ${ }^{3}$

Ook bij de medische vervolgopleidingen heeft de modernisering geleid tot nieuwe aandacht voor de didactische competenties van opleiders. ${ }^{4-5}$ Het Centraal College Medische Specialismen (CCMS) heeft de projectgroep Opleidersprofessionalisering ingesteld om kaders te ontwikkelen waarbinnen de professionalisering van opleiders vorm gegeven dient te worden. Voor artsen in opleiding tot specialist (aios) zijn didactische trainingen bepleit en ontwikkeld. ${ }^{6-8}$ Daar ook in het Raamplan 2009 voor de artsenopleiding de rol van onderwijs nadrukkelijk is opgenomen: "De arts geeft onderwijs en/of bevordert onderwijs aan studenten, patiënten en anderen", ${ }^{9}$ lijkt het logisch ook in de eerste fase van het medisch opleidingscontinuüm aandacht te schenken aan het leren doceren. Het Universitair Medisch Centrum Utrecht heeft daartoe een didactisch programma ontwikkeld waarmee studenten een Studentonderwijskwalificatie (StOK) kunnen behalen, als voorloper van de Basis- en Seniorkwalificaties Onderwijs (SKO). ${ }^{10}$ Dit programma richt zich vooral op studenten in de laatste fase van de opleiding tot basisarts.

In Groningen worden al vele jaren tot grote tevredenheid van alle betrokkenen (Bachelor) student-tutoren ingezet in het onderwijs in de eerste studiejaren. Alvorens aan het werk te gaan worden deze studenten getraind voor hun rol, veelal samen met docenten. Daarnaast werden extra-curriculaire didactische activiteiten voor studenten ontwikkeld, onder andere in de vorm van Summer Schools. Het idee van een gestructureerd didactisch programma voor studenten, vergelijkbaar met het BKO-traject voor docenten, kwam uit de studentengeleding zelf. Dit plan werd positief ontvangen door de Groningse staf, maar wel werden de volgende problemen voorzien: 1) studenten nemen deel aan het reguliere curriculum van hun opleiding waardoor het niet altijd mogelijk is cursussen en workshops te volgen en 2) het is voor studenten niet vanzelfsprekend dat ze eigen onderwijstaken hebben, waardoor extra aandacht besteed moet worden aan een succesvolle invulling van het opdoen van praktijkervaring. Desalniettemin werd besloten een BKO-traject voor studenten een kans te geven, waarbij de voorziene problemen zoveel mogelijk werden opgelost.

Het huidige artikel beschrijft de ontwikkelingen, implementatie en ervaringen van de eerste twee cohorten die instroomden in het BKO-programma voor studenten, waarbij specifiek aandacht besteed wordt aan de twee hierboven geschetste problemen: de roostering van BKO-cursussen en workshops en het opdoen van de nodige onderwijservaring in de praktijk. Om dit in het juiste kader te plaatsen wordt eerst kort het BKO-programma voor docenten (BKO-D) geschetst.

\section{BKO-programma voor docenten in Groningen}

Het Groningse BKO-D opleidingstraject is gebaseerd op het Leids-Groningse competentieprofiel DOCES dat wordt onderverdeeld in vijf competentiegebieden: ontwerpen van een studieonderdeel, uitvoeren van een studieonderdeel, begeleiden van studenten, contextgericht handelen en eigen professionalisering (zie ook: http:// www.uocgmarket.nl/oplossingen.html\#/doces). ${ }^{11}$ Het traject tot het behalen van een BKO beslaat ongeveer twee jaar en vraagt, 
afhankelijk van het uitgangsniveau van de individuele deelnemer, een investering van ongeveer 200 uur. Het programma bestaat, naast de nodige praktische onderwijservaringen, uit een aanbod van didactische cursussen en workshops, intervisie en één-op-één coaching door een medewerker van het Centrum voor Docentprofessionalisering (Figuur 1). Bij de start van het traject stelt de deelnemer een Docent Ontwikkel Plan (DOP) op. Uitgaande van een sterkte/zwakte analyse stelt hij/zij vervolgens vast welke competenties nog verworven moeten worden om aan de eindtermen van de BKO te voldoen. Gedurende het BKO-traject wordt het DOP geleidelijk getransformeerd tot een docentportfolio, waarin concrete onderwijs- producten worden opgenomen, vergezeld van bewijsstukken en reflectieverslagen. Aan het eind van het traject wordt dit docentportfolio getoetst door een daarvoor ingestelde beoordelingscommissie, bestaande uit het hoofd van het Centrum voor Docentprofessionalisering, een andere dan de eigen coach en een senior medewerker uit de onderwijsomgeving van de docent. De procedures en richtlijnen voor de toetsing zijn vastgelegd in overleg met het Universitair Onderwijscentrum Groningen (UOCG) en passen binnen de door de VSNU vastgestelde kaders. Voor meer informatie over het BKO-D programma wordt verwezen naar de website: www.bkogroningen.nl.

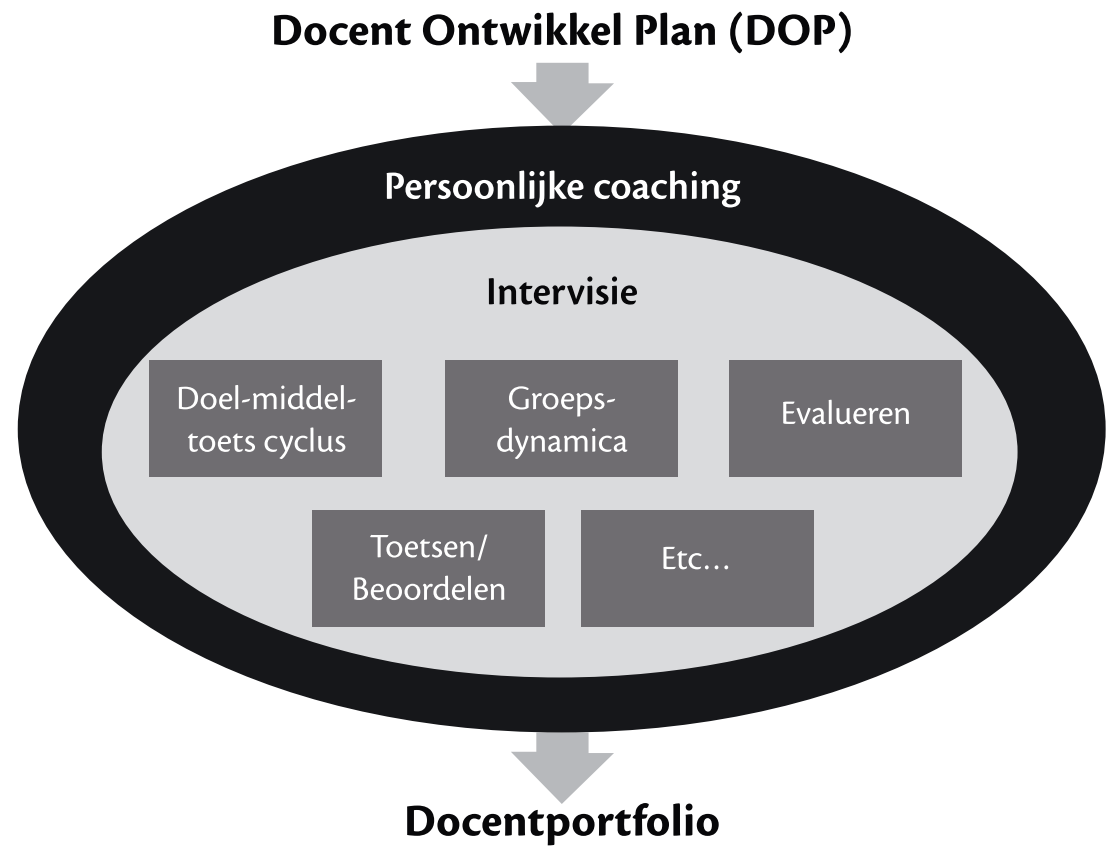

Figuur 1. Het traject tot het behalen van een BKO in Groningen.

De workshops als bouwstenen van het traject, intervisie als cement. Daar omheen drie à viermaal per jaar persoonlijke coaching, waarbij de docent gecoacht wordt bij het opbouwen van een toetsbaar docentportfolio mede gebaseerd op ervaringen in de onderwijspraktijk. De voor de BKO vereiste onderwijservaring is niet opgenomen in deze weergave. 


\section{Opzet}

\section{Uitgangspunten BKO-programma voor studenten (BKO-S)}

Een belangrijk uitgangspunt bij het ontwikkelen van het opleidingstraject voor studenten (BKO-S) was dat zij na afloop voldoen aan dezelfde aan DOCES ontleende eindtermen als de docenten en dat zij op dezelfde wijze getoetst worden. ${ }^{11}$ Het tweejarige opleidingstraject voor docenten vormt daarom de basis van het opleidingstraject voor studenten. Om studenten meer ruimte te geven voor het volgen van de cursussen en het opbouwen van onderwijservaring is er voor gekozen het programma niet over twee, maar over vier jaar te spreiden en zijn er roostertechnische aanpassingen gedaan en extra activiteiten georganiseerd (zie Resultaten). Om te garanderen dat studenten ook voldoende vakinhoudelijke kennis hebben, ontvangen ze het BKO-S certificaat pas bij of na het behalen van het Masterdiploma.

\section{Facilitering van het opdoen van onderwijservaring}

Om BKO-S studenten te faciliteren bij het opdoen van onderwijservaring hebben zij voorrang gekregen bij het vervullen van structurele facultaire onderwijstaken als student-tutorschappen en assistentschappen bij practica. Daarnaast worden vanuit het Onderwijsinstituut korte projecten aangeboden, zoals het ontwerpen en uitvoeren van (niet-standaard) onderwijsevaluaties. BKO-studenten die tevens een MD/PhDtraject doorlopen, kunnen als promovendi studenten begeleiden bij het doen van wetenschappelijk onderzoek. ${ }^{12}$ In de eerste twee jaar van het BKO-traject worden studenten ook aangemoedigd buiten de universitaire muren te kijken.

\section{Evaluatie van het traject}

Voor het analyseren van de ervaringen met het traject werd de deelname aan de diverse cursorische onderdelen op basis van administratieve gegevens in kaart gebracht met als peildatum 1 augustus 2011. Om de onderwijservaringen van de BKO-studenten te inventariseren, werd in februari/maart 2011 per e-mail een enquête gehouden waarin de BKO-studenten gevraagd werd welke ervaringen ze hebben opgedaan vóór aanvang van en tijdens het traject. Zeven BKO-studenten van cohort 2008 (58\%) en acht van cohort 2009 (50\%) deden hieraan mee. De genoemde onderwijsactiviteiten zijn vervolgens ingedeeld in de vijf competentiegebieden van DOCES. ${ }^{11}$

\section{Resultaten}

\section{Het BKO-S programma}

Het ontwikkelde programma is wat betreft de eindtermen en de inhoud gelijk aan het programma voor docenten, maar kent ook enkele verschillen (Tabel 1).

\section{Deelname aan cursusaanbod en Summer Schools}

In het eerste opleidingsjaar werden cursussen voor studenten en docenten separaat ingeroosterd, maar met de start van cohort 2009 vervaagde de grens tussen beide scholingsroosters geleidelijk en werden trainingen aan gemengde groepen gegeven. Op de peildatum van 1 augustus 2011 hebben gemiddeld 10,5 van de 12 (88\%) studenten van cohort 2008 en gemiddeld acht van de zestien $(50 \%)$ studenten van cohort 2009 deelgenomen aan de hen aangeboden cursussen. De Summer Schools - verzorgd op vier aaneengesloten dagen in juli - werden opvallend goed bezocht: 22 van de 28 studenten (79\%) namen deel aan de Summer School over 'Vaardigheidsonderwijs' en 23 van de 28 (82\%) aan de Summer School over 'Toetsing'. 
Tabel 1. Overeenkomsten en verschillen van de BKO-S ten opzichte van de BKO-D.

\begin{tabular}{|c|c|c|}
\hline Aspecten & Traject BKO-D & Traject BKO-S \\
\hline \multicolumn{3}{|l|}{ Kaders / randvoorwaarden } \\
\hline Kader voor trajectontwerp & $\begin{array}{l}\text { BKO-convenant } 2008 \text { (VSNU), } \\
\text { vijf competenties }\end{array}$ & \\
\hline \multicolumn{3}{|c|}{ Het opleidingstraject binnen het UMCG } \\
\hline Opzet van het traject & $\begin{array}{l}\text { cursusprogramma, één-op-één } \\
\text { coaching, intervisie }\end{array}$ & \\
\hline Wijze van eindbeoordeling & $\begin{array}{l}\text { portfolio met bewijsstukken } \\
\text { en reflectieverslagen }\end{array}$ & \\
\hline Duur van het traject & $\begin{array}{l}\text { twee jaar, maximaal } \\
200 \text { uur totaal }\end{array}$ & $\begin{array}{l}\text { vier jaar, minimaal } \\
200 \text { uur totaal }\end{array}$ \\
\hline \multicolumn{3}{|l|}{ Facilitering tijdens het traject } \\
\hline Tijdsbesteding & grotendeels onder werktijd & extracurriculair \\
\hline $\begin{array}{l}\text { Verwerven van } \\
\text { onderwijservaring }\end{array}$ & vanuit eigen takenpakket & $\begin{array}{l}\text { deels gefaciliteerd (tutorschap, } \\
\text { studentassistentschap), deels } \\
\text { eigen initiatief }\end{array}$ \\
\hline \multicolumn{3}{|l|}{ Cursusprogramma } \\
\hline Aanbod aan onderwerpen & alle eindtermen dekkend & $\begin{array}{l}\text { idem, plus enkele } \\
\text { extra modules } \\
\text { (presentatietechnieken, } \\
\text { literatuur zoeken) }\end{array}$ \\
\hline Wijze van aanbieden & $\begin{array}{l}\text { elke drie tot vier weken een } \\
\text { module }\end{array}$ & $\begin{array}{l}\text { elke vier tot zes weken een } \\
\text { module, en twee Summer } \\
\text { Schools waarin modules zijn } \\
\text { geclusterd }\end{array}$ \\
\hline
\end{tabular}

\section{Praktijkervaring}

Voor veel studenten bleken eerder opgedane onderwijservaringen de aanleiding geweest te zijn voor deelname aan het BKO-S traject (Tabel 2). Ook daarna lieten ze zien zeer creatief te zijn in het vinden van mogelijkheden om onderwijservaring op te doen, zowel binnen als buiten de universiteit. Zo is in 2008 een structureel programma tot stand gekomen, waarbij studenten uit het
BKO-S programma jaarlijks jongerejaars studenten geneeskunde didactisch trainen in het geven van EHBO-les op basisscholen. ${ }^{13}$ Eén studente werd zelfs in de gelegenheid gesteld een hoorcollege voor een volledige jaarklas van 400 studenten te verzorgen, tot grote tevredenheid van deze studenten. $\mathrm{Zij}$ fungeerde daarmee tevens als een aansprekend rolmodel voor jongere studenten. De begeleidende docent gaf gestructureerde 
Tabel 2. Overzicht van de door de BKO-studenten uit cohort 2008 en 2009 opgedane onderwijservaringen.*

\begin{tabular}{l}
\hline Vóór aanvang van het BKO-S traject \\
\hline Ontwerpen studieonderdeel \\
- Gediplomeerd docent buitensportactiviteiten \\
$(n=1)$
\end{tabular}

\section{Begeleiden studenten}

- Begeleiden van kleine groepen bij geneeskunde en bewegingswetenschappen bij begrip van de studiestof (tutor) $(n=3)$

- Werkgroepen begeleiden universiteit $(n=2)$

- Bijles aan medestudenten (peer-teaching) $(n=2)$

\section{Contextgericht handelen}

- Klankbordgroep/Leerlingenraad middelbare school $(n=3)$

- Medezeggenschap (o.a. jaarvertegenwoordiging) $(n=1)$

\section{Eigen professionalisering}

- N.v.t.

\section{Tijdens het BKO-S traject}

\section{Ontwerpen studieonderdeel}

- Ontwikkelen van diverse workshops binnen de studies geneeskunde, tandheelkunde en bewegingswetenschappen (gericht op onderzoek en/of onderwijs, zoals statistiek, anatomie en fysiologie) $(n=6)$

- (Hoofd)docent examentraining voor middelbare scholieren (Stichting Studiebegeleiding Leiden) $(n=4)$

- Examenvragen opstellen $(n=3)$

- Hoorcollege tweedejaars studenten geneeskunde $(n=1)$

\section{Verzorgen studieonderdeel}

- Uitvoeren van diverse workshops binnen de studies geneeskunde, tandheelkunde en bewegingswetenschappen (gericht op onderzoek en/of onderwijs, zoals statistiek, anatomie en fysiologie) $(n=10)$

- Verzorgen onderwijs aan mede co-assistenten (peer-teaching) $(n=8)$

- Verzorgen van diverse lessen op basis- en middelbare scholen $(n=7)$

- (Assistent-)docent diverse sporten $(n=4)$

- Hoorcollege tweedejaars studenten geneeskunde $(n=1)$

\section{Begeleiden studenten}

- Tutor, mentor en coach bij geneeskunde en bewegingswetenschappen $(n=8)$

- Werkgroepen begeleiden $(n=5)$

- Begeleiden practica studenten (anatomie, fysiologie) $(n=4)$

- Begeleiden van studenten binnen onderzoeksprojecten en ter voorbereiding op bloktoetsen ((near-)peer training) $(n=2)$

- Superviseren beginnende mede-tutoren $(n=1)$

\section{Contextgericht handelen}

- Diverse medezeggenschapsfuncties op ziekenhuis-, facultair, universitair en interuniversitair niveau $(n=7)$

- Deelname aan projectgroep curriculumvernieuwing Groningen $(n=1)$

- Ontwikkelen van een nieuwe evaluatiemethodiek voor beoordeling van professioneel gedrag $(n=2)$

\section{Eigen professionalisering}

- Deelname aan verscheidene congressen en symposia gericht op onderwijs (NVMO, LMSO) ( $n=4)$

- Publiceren van onderwijsgerelateerde manuscripten $(n=4)$

* in aflopende volgorde van frequentie. 
en zeer positieve feedback, maar gaf wel aan dat dit hem veel tijd had gekost. Verder gebruiken BKO-studenten verplichte onderwijsactiviteiten in het curriculum voor hun portfolio, door deze te evalueren, didactische verdieping toe te passen en er achteraf uitgebreid op te reflecteren. Tenslotte werden voorbereidingsopdrachten voor BKOtrainingen gebruikt om vaardigheden te verwerven in verschillende competentiegebieden. Zo bereidden voor de training 'context gericht handelen' alle deelnemers een korte presentatie voor over de context van het eigen onderwijs binnen de opleiding en in relatie tot de onderwijsvisie van de instelling. Voorafgaand aan de training 'schriftelijke toetsen' werden door deelnemers multiple choice vragen aangeleverd, die verwerkt werden tot een door de deelnemers te maken toets; tijdens de training werden de toetsvragen, mede op basis van de statistische toetsanalyse, besproken. Enkele studenten leverden ook daadwerkelijk vragen aan voor nog af te nemen toetsen.

\section{Discussie/conclusie}

Binnen het Onderwijsinstituut van de Faculteit Medische Wetenschappen van het UMCG is een opleidingstraject ontwikkeld en geimplementeerd waarmee studenten geneeskunde, tandheelkunde en bewegingswetenschappen een Basiskwalificatie Onderwijs voor studenten kunnen behalen. De op DOCES gebaseerde eindtermen die gehanteerd zijn voor dit BKO-S traject, zijn gelijk aan die van het BKO-traject voor docenten. Gekwalificeerde studenten ontvangen het BKO-S certificaat gelijktijdig met of na uitreiking van het Masterdiploma, waarmee wordt benadrukt dat de betreffende student niet alleen over de nodige didactische kennis en vaardigheden, maar ook over voldoende vakinhoudelijke kennis beschikt.

Bij aanvang van het traject werden twee moeilijkheden voorzien, te weten: de gele- genheid voor studenten om de didactische scholingsactiviteiten in te roosteren en de mogelijkheid voor het opdoen van onderwijservaring. Gemeten aan de deelname van studenten is de verlenging van het traject en de concentratie van trainingen in Summer Schools een goede oplossing voor het roosterprobleem gebleken. Het laten deelnemen van studenten aan de voor docenten ingeroosterde trainingen had zelfs voor zowel deelnemende studenten en docenten als trainers meerwaarde door de inbreng vanuit verschillende perspectieven. Het tweede gesignaleerde knelpunt was het opdoen van onderwijservaring. Door BKO-studenten structureel voorrang te geven bij sollicitaties voor student-tutoren en andere structurele onderwijsfuncties kon hier voor een groot deel aan tegemoet gekomen worden. Met het beter bekend worden van het BKO-traject en de vele positieve ervaringen vragen ook steeds meer docenten specifiek naar BKOstudenten om onderwijstaken uit te voeren of te ondersteunen. Het maken van opdrachten voorafgaand of tijdens de trainingen bleek eveneens een efficiënte manier om kennis en vaardigheden te verwerven. Tenslotte bleken studenten zelf diverse mogelijkheden te vinden om onderwijservaring op te doen in alle competentiegebieden. Een knelpunt hierbij is de inzet die gevraagd wordt van begeleidende docenten. Enkele docenten gaven specifiek aan niet aan dit 'experiment' deel te willen nemen gezien de tijdsinvestering, maar noemden ook het niet 'aan te durven'. Ondanks alle creativiteit en inzet zal de breedte en omvang van de praktijkervaring van de gemiddelde student toch achterblijven bij die van de gemiddelde docent in het BKO-traject. Om dit tot uitdrukking te brengen wordt aan studenten een BKO-S certificaat gegeven met daarbij een uitgebreid portfolio beoordelingsverslag waarin wordt aangegeven welke onderwijservaring werd opgedaan (Box 1). 
Box 1. Tekst op het BKO-certificaat.

De BasisKwalificatie Onderwijs voor studenten (BKO-S) geldt als bewijs van didactische voorbereiding op het geven van wetenschappelijk onderwijs.

De houder van dit certificaat heeft bewezen competent te zijn in de volgende deelgebieden:

$>$ (Her)ontwerpen van een studieonderdeel

$>$ Verzorgen, toetsen en evalueren van een studieonderdeel

$>$ Begeleiden van studenten

$\mathrm{Hij} / \mathrm{zij}$ heeft aangetoond bovengenoemde competenties toe te kunnen passen in de onderwijspraktijk en heeft blijk gegeven voldoende vermogen tot zelfreflectie te hebben voor blijvende didactische professionalisering.

Deelnemers aan het BKO-S traject hebben hetzelfde trainings- en begeleidingsprogramma gevolgd als deelnemers aan het BKO traject voor docenten en zijn op dezelfde wijze getoetst op basis van een onderwijsportfolio. Dit BKO-certificaat werd uitgereikt bij het Masterdiploma «geneeskunde/ tandheelkunde/bewegingswetenschappen», waarmee de inhoudelijke vakkennis is gegarandeerd.

Tijdens het BKO-S traject werd ervaring opgedaan binnen (en buiten) het universitaire onderwijs; voor nadere details wordt verwezen naar het uitgebreide beoordelingsverslag en het hieraan ten grondslag liggende portfolio.

Individuele coach tijdens het traject tot het behalen van de BKO-S was «coach».

Ondanks de enthousiaste deelname aan het scholingsprogramma zullen niet alle studenten het gehele traject afmaken. Hierbij spelen verschillende (combinaties van) factoren een rol. Uit individuele gesprekken met studenten blijkt dat degenen die in het begin van het traject ermee ophouden dit veelal doen omdat ze de extra inspanningen die gevraagd worden hebben onderschat. In een latere fase is een belangrijke factor dat studenten in het tweede en veelal ook in het derde jaar van de Masteropleiding buiten Groningen verblijven, waarmee ze het directe contact met hun coach en mededeelnemers verliezen; verder stelt de overgang naar de klinische fase veelal grotere en andere eisen dan de voorgaande jaren. ${ }^{14}$ Hoewel, of misschien doordat, studenten vanuit het reguliere curriculum al gewend zijn aan het opbouwen van een portfolio blijkt het opbouwen van een docentportfolio vaak een sluitpost te zijn in het BKO-traject. Dit lijkt eerder te berusten op tijdgebrek en motivatie dan op een onvermogen tot reflectie; dit laatste blijkt uit een beperkte analyse en ervaringen van de coaches bij de meeste studenten juist goed ontwikkeld te zijn. ${ }^{15}$ Daarnaast geven studenten als reden van stoppen aan dat ze vooral geïnteresseerd zijn in een (theoretische) verdieping in onderwijs en dat ze die voldoende hebben gekregen door deel te nemen aan de cursorische onderdelen. Om de beperkte capaciteit van het BKO-S programma beter te benutten lijkt vooral betere voorlichting en selectie van belang, alsook het stellen van strengere eisen aan de opbouw van het portfolio in de eerste jaren van deelname aan het traject. Ook om organisatorische redenen zal selectie nodig zijn omdat het aantal aanmeldingen 
tot nu toe meer dan het dubbele is van het aantal beschikbare plaatsen van maximaal 20 per jaar.

Het is mogelijk gebleken studenten een extracurriculair didactisch scholingsprogramma te laten volgen, dat vergelijkbaar is met het BKO-programma voor docenten. Dit traject biedt de studenten ook andere voordelen dan toegenomen didactische kennis en vaardigheden, zowel tijdens als na het opleidingstraject. Vanuit de literatuur is bekend dat deelname aan didactische opleidingstrajecten diverse aspecten van de medische opleiding vergemakkelijkt, verrijkt of verdiept; bijvoorbeeld de communicatie met zorgprofessionals en patiënten. ${ }^{16-23}$ Er zijn tevens aanwijzingen dat deelname aan didactische trainingen een positief effect heeft op het leer- en studeergedrag van de betrokken studenten.

Ook de onderwijsorganisatie kan de vruchten plukken van het BKO-S traject. Studenten die het BKO-S certificaat behaald hebben, zijn toegerust om meteen onderwijstaken te gaan vervullen. Dit biedt de onderwijsorganisatie een uitgelezen mogelijkheid om jonge medewerkers, intrinsiek gemotiveerd voor het geven van onderwijs, te werven en in het eigen curriculum in te zetten in het onderwijs. Bijkomend voordeel is dat deze jonge docenten de didactische setting van haver tot gort kennen en als ervaringsdeskundigen de sterke maar ook de zwakke elementen ervan reeds kennen.

Het is tevens opvallend dat BKO-S studenten bovengemiddeld vaak medezeggenschapsfuncties op ziekenhuis-, facultair, universitair en/of interuniversitair niveau vervullen. Voor de onderwijsorganisatie is dit een extra argument om deze gemotiveerde en betrokken groep aan zich te binden en een concrete start te maken met het implementeren van recent geformuleerd universiteitsbreed beleid dat me- dewerkers stimuleert een carrière in het universitaire onderwijs na te streven. In hoeverre de studenten die het BKO-traject hebben gevolgd beter onderwijs geven en wat het effect op de doelgroep is, zal nader geanalyseerd moeten worden.

\section{Literatuur}

1. VSNU (2008) Overeenkomst inzake wederzijdse erkenning basiskwalificatie onderwijs. http://www. vsnu.nl/web/file?uuid $=52 \mathrm{c} 4 \mathrm{~d} 2 \mathrm{fc}-\mathrm{a} 7 \mathrm{e} 8-4 \mathrm{abe}-940 \mathrm{f}-$ $10 \mathrm{e} 82 \mathrm{f} 768 \mathrm{~d} 7 \mathrm{~b} \&$ owner $=811 \mathrm{ee} 19 \mathrm{~b}-5 \mathrm{f} 57-4829-\mathrm{bb} 05$ $942 \mathrm{c} 31 \mathrm{~b} 3 \mathrm{dfab}$ [Agreement on mutual recognition of basic teaching qualification].

2. VSNU (2008) Overeenkomst inzake wederzijdse erkenning basiskwalificatie onderwijs, Bijlage: Kenmerken van de regeling BasisKwalificatie Onderwijs (BKO) http://www.vsnu.nl/web/file? uuid $=6 \mathrm{cf} 20 \mathrm{c} 59-\mathrm{f} 970-4 \mathrm{a} 0 \mathrm{e}-98 \mathrm{c} 3-\mathrm{dc} 98 \mathrm{bfc} 221 \mathrm{f} 7$ \&owner=f9c3ac54-28ac-4945-b499-c31d3fa31878 [Agreement on mutual recognition of basic teaching qualification. Appendix: Characteristics of the regulation of the Basic Teaching Qualification (BKO)].

3. Van den Berg C. Basiskwalificatie onderwijs op de (bestuurlijke) agenda. Onderzoek van onderwijs 2007; 36: themanummer 'docentprofessionalisering'. [Basic Teaching Qualification on the (administrative) agenda. Special issue on facculty development].

4. Bolhuis S, Fluit CRMG, Venekamp R, Boendermaker PM. Naar scholing voor opleiders in de specialistische vervolgopleidingen. Tijdschrift voor Medisch Onderwijs 2005;24(2):72-77. [Developing educational training for specialist trainers. Netherlands Journal of Medical Education 2005;24(2):72-77].

5. Fluit CRMG, Heineman MJ, Baane JA, de Leede BJA, Mulder H. Professionalisering van opleiders: Leren opleiden met en van elkaar. Tijdschrift voor Medisch Onderwijs 2008;27(6):288-295. [Postgraduate trainers and trainees learn with and from one another how to become professional clinical teachers. Netherlands Journal of Medical Education 2008;27(6):288-295].

6. Borleffs JCC, Cate ThJ ten, Bruijnzeel-Koomen CAFM, Erkelens DW. Pleidooi voor een stage klinische onderwijskunde binnen de specialistenopleiding. Tijdschrift voor Medisch Onderwijs 2002;21(1):25-32. A plea for a clinical education internship in postgraduate specialty training. Netherlands Journal of Medical Education 2002; 21(1):25-32].

7. Ottink MD, Busari JO, Essed CGM. Leren leren leren doceren: Een cursus didactische professio- 
nalisering voor aios. Tijdschrift voor Medisch Onderwijs 2008;27(5):239-246. [Learn to learn, learn to teach: a course on didactic skills for residents. Netherlands Journal of Medical Education 2008;27(5):239-246].

8. Busari JO, Scherpbier AJJA, Van der Vleuten CPM, Essed GGM. A Two-Day Teacher-Training Programme for Medical Residents: Investigating the Impact on Teaching Ability. Adv Health Sci Educ 2006;11(2):133-144.

9. Van Herwaarden CL, Laan RF, Leunissen RR. Art. 5.2 "Academicus". Raamplan artsenopleiding 2009 http://www.vsnu.nl/Media-item/RaamplanArtsopleiding-2009.htm ["University graduate". The 2009 Framework for undergraduate medical education in the Netherlands].

10. Spermon J, Bleijs RLAW, Fick TE, Ten Cate ThJ. Een onderwijskwalificatie voor studenten. Tijdschrift voor Medisch Onderwijs 2006;25(5):202207. [A teacher qualification for medical students. Netherlands Journal of Medical Education 2006;25(5):202-207].

11. Brants J, Groot CG, Joostens TH, Pols L. Competenties van docenten in het wetenschappelijk onderwijs. Inventarisatie en instrumentenontwikkeling. Rijksuniversiteit Groningen, ICLON Universiteit Leiden i.o.v. Ministerie van Onderwijs, Cultuur en Wetenschappen. 2002. [Teaching competencies for higher education. Overview and instrument development].

12. Hooiveld MHW, Kluin-Nelemans JC. Junior Scientific Masterclass. Groningse professionele kweekvijver om studenten tot artsonderzoeker op te leiden. Tijdschrift voor Medisch Onderwijs 2007; 26(6):288-296. [The Groningen Junior Scientific Master Class: a breeding ground for medical researchers. Netherlands Journal of Medical Education 2007;26(6):288-296].

13. Pleijhuis RG, Stegmann ME, Verbeek T, Schultinge L, Kleef AJG van, Bos FM, Molenaar WM. Studenten trainen medestudenten als onderdeel van het opleidingstraject Basiskwalificatie Onderwijs (BKO). Tijdschrift voor Medisch Onderwijs 2011;30(4):143-151. [Peer teaching of didactic skills by medical students. Netherlands Journal of Medical Education 2011;30(4):143-151].

14. Prince CJAH, Van de Wiel MWJ, Scherpbier AJJA, Van der Vleuten CPM, Boshuizen HPA. De overgang van theorie naar praktijk in het medisch curriculum. Tijdschrift voor Medisch Onderwijs 2000;19(6): 200-207. [The transition from theory to practice in the undergraduate medical curriculum. The Netherlands Journal of Medical Education 2000;19(6): 200-207].
15. Molenaar WM, Bos FM, Sillius AW. Medical students' in an extracurricular educational program: does interviewing teachers enhance the students perceptions of their role as future teachers? Paper Association for Medical Education in Europe (AMEE)-congress 2009 (abstract 3AA10).

16. Dandavino M, Snell L, Wiseman J. Why medical students should learn how to teach. Med Teach 2007;29(6):558-565.

17. Bardach NS, Vedanthan R, Haber RJ. 'Teaching to teach': enhancing fourth year medical students' teaching skills. Med Educ 2003;37(11):1031-1032.

18. Dolmans D. Students as teachers. Med Educ 2000;34(1):11-12.

19. Nestel D, Kidd J. Evaluating a teaching skills workshop for medical students. Med Educ 2002;36(11):1094-1095.

20. Morrison EH, Lewis EM, Gabbert CC, Boker JR, Kumar B, Harthill M. Evaluating a 'service elective' in clinical teaching for medical students. Med Teach 2003;25(6):662-663.

21. Paiva RE, Kienzler LM, Anderson MB. Preparation for the teaching role in residencies: an elective for medical students. J Med Educ 1982;57:792-794.

22. Pasquale SJ, Pugnaire MP. Preparing medical students to teach. Acad Med 2002;77(11):1175-1176.

23. Drouin J, Denis M, Nadeau L, Chenier Y. Medical students as teachers and role models for their future colleagues. Med Teach 2006;28(7):618-624.

\begin{abstract}
De auteurs:
T. Verbeek BSc, R.G. Pleijhuis BSc, A.J.G. van Kleef BSc, M.E. Stegmann MD, L. Schultinge BSc zijn studenten geneeskunde die hebben deelgenomen aan het BKO-S traject in het UMC Groningen.

Prof. dr. W.M. Molenaar is hoofd van het Centrum voor Docentprofessionalisering, Universitair Medisch Centrum Groningen.

Dr. ir A.W. Sillius en F.M. Bos MSc zijn medewerkers van het Centrum voor Docentprofessionalisering, Universitair Medisch Centrum Groningen.
\end{abstract}

\section{Correspondentieadres:}

Prof. dr. W.M. Molenaar, Onderwijsinstituut FMW, Sector F, Postbus 196, 9700 AD Groningen. Tel. 0503632887.E-mail:w.m.molenaar@umcg.nl

Belangenconflict: geen gemeld

Financiële ondersteuning: geen gemeld 


\section{Summary}

Introduction: The Basic Teaching Qualification ('BKO') is considered proof of didactic competence for university teachers in the Netherlands. In University Medical Center Groningen, there were calls to offer a similar programme for students. Two difficulties were foreseen: the (im)possibility for students to schedule the didactic courses alongside their regular coursework and the acquisition of teaching experience.

Method: A special programme (BKO-S) was launched for students in medicine, dentistry and human movement sciences aimed at the same level as the teacher programme. The course scheduling problem was resolved by extending the programme to four years instead of two and by clustering some courses in summer schools. Facilitating teaching opportunities for the BKO students largely resolved the second difficulty. Nevertheless, the average student in the programme will have less teaching experience than the average teacher in the BKO programme. To express this, the students will receive a $B K O-S$ certificate, accompanied by a portfolio assessment report specifying their teaching activities.

Results: Two cohorts of twelve and sixteen Bachelor students entered the programme in 2008 and 2009, respectively. Attendance at the courses and the summer schools was high. The students were very creative in finding teaching opportunities. Since 1 August 2011, two students have completed the programme and had their portfolios approved. They will receive the BKO-S certificate with their Master's degree.

Discussion/conclusion: Adaptations of the teacher training programme have enabled medical students to successfully participate in a similar teacher training programme alongside the regular undergraduate programme. (Verbeek $T$, Pleijhuis RG, Van Kleef AJG, Stegmann ME, Schultinge L, Sillius AW, Bos FM, Molenaar WM. Experiences with a Basic Teaching Qualification for students (BKO-S). Netherlands Journal of Medical Education 2011;30(6):272-282.) 